\title{
Making Good Arguments in Archaeology
}

Michael E. Smith, mesmith9@asu.edu March 16, 2021. Author's typescript.

Paper solicited for the volume, Discourse and Argumentation in Archaeology: Conceptual and Computational Approaches, edited by Patricia M. Rodilla, César González-Pérez and Martín Pereira-Fariña. Planned for publication by Springer.

After some serious missteps by Lewis Binford and the other new archaeologists in the 1970s, most archaeologists stopped paying attention to the forms of argumentation in our field. Discussions of the use of analogy continued for a while longer (Wylie, 1985), but they eventually died down. Postprocessualists and scientifically-minded archaeologists alike avoided the topic of argumentation, leaving the theme of archaeological epistemology impoverished. Recently, however, attention to arguments in archaeology has started to grow again (Smith, 2017; Chapman and Wylie, 2015; 2016; Smith, 2015b; Orser, 2014; Currie, 2016). The present chapter is written as a contribution to this line of work.

I first review historical reasons for the lack of attention to argumentation in recent decades. Next, I review the status of archaeological argumentation as set out in a 2015 paper (Smith, 2015b). This is followed by an expansion of this line of thought based on a methodological approach initiated by Stephen Toulmin in 1958 (Toulmin, 2003). Toulmin's scheme is based on visual diagrams to show the sequential steps in an argument. It is a particularly helpful method to show the difference between strong and weak archaeological arguments about the past. My final topic is an examination of archaeological modeling as a form of argument.

\section{The Historical Lack of Attention to Argumentation in Archaeology}

After a flurry of interest in explanation and argumentation by Lewis Binford and the new archaeologists from the mid-1960s to the mid-1980s, these topics receded into the archaeological woodwork. Although archaeologists continued to make arguments and explain their findings, there was little published epistemological work (that is, works dealing explicitly with methods of knowledge generation in archaeology ${ }^{1}$ ). This contributed to a decline in both the explicitness and the quality of argumentation. By the 2010's, the misuse of argument by analogy was widespread. Publications on the methods and context of archaeological argumentation began to reappear, however (Gibbon, 2014; Smith, 2015b; Chapman and Wylie, 2016; Smith, 2017).

In a recent paper, I claimed that the new archaeologists promoted "faulty views of science and explanation, \{which\} caused great harm to archaeology by setting scientifically minded archaeologists on an unproductive tangent" (Smith, 2017:521). This claim points up a gap in Alison Wylie's otherwise excellent philosophical and historical accounts of explanation and arguments in archaeology (Wylie, 1985; 2002; Chapman and Wylie, 2016). This gap concerns the fate of argumentation during and after the "theory wars" between the new archaeologists and the postprocessualists. Wylie has noted that the loud debates largely subsided from public view, and goes on to observe that, "An unreflective 'live and let live' pluralism exempts a great many untenable assumptions from reasoned examination" (Wylie, 2017a:129). What she has failed to examine is the spread of weak arguments by the postprocessualists and 
their descendants. I believe that one reason for this is the lack of a robust epistemological literature in archaeology that provides guidelines on acceptable arguments and explanations.

Lewis Binford and the new archaeologists adopted the covering law approach associated with Carl Hempel (1965) and the logical positivist philosophers of science. The most explicit and strident statement of this choice was the book Explanation in Archaeology: An Explicitly Scientific Approach (Watson et al., 1971). To explain an event, these authors claimed, is to subsume the event under a general law, which then implies that the law explains the event. By the time the new archaeologists had adopted what Wylie (2002) calls "Hempelian positivism," philosophers of science had already rejected this approach to explanation as inappropriate for the social and historical sciences. Indeed, the explanatory approach of Watson et al. was criticized by a philosopher of science (Morgan, 1973). Watson et al. responded to this critique by saying that as a philosopher of science, Morgan didn't know anything about archaeology, and therefore he should leave them alone (Watson et al., 1974).

Independent of the philosophy of science, some archaeologists were quick to criticize the use of Hempel and covering laws by their colleagues. Jeremy Sabloff et al. (1973:112) called this work "naïve," and Kent Flannery (1973:51) — never one to mince his words - opined that the Hempelian approach "has produced some of the worst archaeology on record." The only covering laws archaeologists could come up with were so trivial that Flannery called them "Mickey Mouse laws" (p. 51).

In the wake of the archaeological theory wars, neither camp engaged publicly or published on the issue of argumentation. The postprocessualists - in their embrace of social constructivism, interpretivism, and the primacy of meaning-ignored explicit considerations of argumentation and explanations. In the words of Bruce Trigger (2006:466), "neither LeroiGourhan nor Hodder discovered how to advance beyond speculation in interpreting the meaning of such regularities." Postprocessualists avoided engagement with the philosophy of science concepts on these topics, with one exception. That exception was a claim that logical positivism was synonymous with science, and therefore the more general rejection of logical positivism as an adequate explanatory framework implied that science was not appropriate for archaeology. See my discussion of Matthew Johnson (2010) for documentation of this claim (Smith, 2017). If Johnson and other postprocessualists (e.g., Martinón-Torres and Killick, 2013) were correct on this matter, then much of science - from genetics to astronomy-would cease to exist. But, of course, neither archaeology nor the hard sciences have used the covering law approach for many decades. Whether this claim originated in ignorance or guile, it does nothing to advance argumentation or theory in archaeology.

The new archaeologists and their descendants, whose theoretical approach has been called "processualist-plus" (Hegmon, 2003), similarly failed to engage explicitly with epistemological issues surrounding arguments and explanation, although there were a few exceptions (e.g., Fogelin, 2007). Archaeologists employing a scientific epistemology largely put their heads down, worked on their own materials with the best explanatory schemes they knew of, and stayed away from public discussion of arguments and explanations. In Trigger's (2006:462) words, "Although American archaeologists were increasingly open to theoretical diversity, most of them lacked the ambition to try to determine in an operational manner under what circumstances specific sorts of theories were and were not applicable." 
I recall this period well; it covers the early portion of my own career. I tried to conduct my archaeology using a scientific perspective, but was frustrated with the lack of epistemological discussion of how to improve archaeological arguments. Nearly all of the professional debate was on the level of social theory, not epistemology. Around 2010 I began reading in social science disciplines beyond my home discipline of anthropology, largely to learn about research on cities and neighborhoods. I was pleasantly surprised to find an active epistemological literature on explanation and argument, particularly in the fields of sociology, political science, and historical social science (Tilly, 2008; Gerring, 2012; Abbott, 2004; Mahoney et al., 2009). I learned that covering law explanations were absent from these fields, and that causal mechanisms provided the dominant form of explanation (Demeulenaere, 2011; Hedström, 2005). The social-science works cited above led me to the philosophy of social science and history for suggestions on how to improve argumentation in archaeology (Bunge, 2004; Little, 2010; Manicas, 2006).

\section{Archaeological Argumentation in 2015}

My 2015 paper on argumentation (Smith, 2015b) included three broad critiques of widespread archaeological practices of argumentation and explanation: the lack of testing of ideas; the poor use of methods of analogy; and a reliance on abstract, philosophical social theory. In this section I review the current status of these issues and provide background for a discussion of Stephen Toulmin's methods for analyzing arguments.

\section{The Importance of Testing}

I began my 2015 paper with the following quotation: "The fundamental question of all serious fields of scholarly inquiry $\{$ is $\}$ : How would you know if you are wrong?" (Haber, 1999:312). This notion derives from Karl Popper's (1934) concept of falsifiability. For Popper, scientific explanations must be falsifiable. He emphasized crucial experiments that can falsify definitively one or more propositions. In the social sciences, however, such definitive experiments are rare. In the words of John Gerring (2012:31), "Some theories and more falsifiable than others." In their textbook on social science methods, Charles Ragin and Lisa Amoroso discuss the importance of testing as follows:

By testing hypotheses, it is possible to improve the overall quality of the pool of ideas. Ideas that fail to receive support gradually lose their appeal, while those that are supported more consistently gain greater stature in the pool. While a single unsuccessful hypothesis rarely kills a theory, over time, unsupported ideas fade from current thinking. It is important to identify the most fertile and powerful ways of thinking and to assess different ideas, comparing them as explanations of general patterns and features of social life. Testing theories can also serve to refine them. By working through the implications of a theory and then testing this refinement, it is possible to progressively improve and elaborate a set of ideas. (Ragin and Amoroso, 2011:39).

This emphasis on testing is almost universal in the literature on social science methods. Perri 6 and Christine Bellamy (2012:52) conclude a discussion of Popper's views by observing that, for social scientists, "to meet scientific standards of rigour, theories must be stipulated in ways that make them empirically testable." Philosopher of science Mario Bunge, discussing Bruce Trigger's approach to archaeology, states that the scientific method "may be boiled down 
to the rule, check your guesses" (Bunge, 2013:153). Perhaps not surprisingly, quite a few postprocessualist archaeologists are on record opposing the usefulness of testing. Mathew Johnson (2010:223), for example, argues that archaeologists should "shift form a language of 'testing' to a language of 'evaluation'," and Ian Hodder and Scott Hutson (2003:239) claim that, "Instead of testing, we come to an understanding."

The post-hoc argument is a type of untested — and untestable — argument common in archaeology. I quote from my 2015 paper on this:

Lewis Binford (1981) discussed problems with this procedure, which he called "posthoc accommodative argument." He was referring to an interpretation that is applied to the data and findings once the research activities are complete. The problem with post-hoc arguments is that they can't be shown to be wrong. The analysis is done, and the post-hoc interpretation cannot be disproven without another round of research. We can all dream up numerous alternatives to explain (or explain away) any set of findings. But without some form of testing, post-hoc arguments serve to introduce potentially faulty or misleading interpretations into the literature. (Smith, 2015b:19).

As pointed out by Geoffrey Clark (2000:852), such arguments are common in the field of paleoanthropology, in spite the fact that, "it is a weak form of explanation." In some branches of psychology, post-hoc arguments are strongly condemned not only as problematic arguments but also as ethical lapses (Kerr, 1998; Leung, 2011). A common analogy for post-hoc arguments is a farmer who paints bulls-eyes around the bullet holds in his barn to show off his superior shooting skill.

\section{The Decline of Argument by Analogy}

A large and sometimes contentious literature on the use of "ethnographic analogy" in Americanist archaeology was synthesized and formalized by Alison Wylie's paper, "The Reaction Against Analogy" (Wylie, 1985). Nearly all of the explicit archaeological uses of the method of analogy - from Lewis Binford and the new archaeologists through Wylie's paperwere in the form of inductive logic. Indeed, Wylie's criteria for assessing the strength of an argument by analogy are almost identical to the criteria for inductive inferences as discussed in textbooks on logic (Copi, 1982:397-400). Analogies are neither correct nor incorrect; instead, they are more or less useful, typically depending on their strength. Here is what Wylie said about the strength of analogies:

The standard criteria for evaluating what I have described as formal analogies are, then: the number and extent of similarities between source and subject; the number and diversity of sources cited in the premises in which known and inferred similarities co-occur as postulated for the subject; and finally, expansiveness of the conclusions relate to the premises (Wylie, 1985:98).

The two strategies developed for strengthening formal analogy — the strategies of expanding the base of interpretation and elaborating the fit between source and subject - must be treated as directives for the active investigation of sources and subjects rather than as criteria for assessing analogical conclusions reflectively, after they are formulated. And the inquiry they initiate must be specifically designed to determine what causal connections hold between the material and cultural or 
behavioral variables of interest, and under what conditions these connections may be expected to hold (Wylie, 1985:101).

This approach to argument by analogy - a formal argument based on the rules of inductive logic — has been abandoned by many archaeologists in the decades since 1985. I discuss two of the resulting problems in my 2015 paper (ad-hoc analogies and empty citations), and here I add a third difficulty: the use of complex, untested analogues.

(1) I described the problem of "ad-hoc analogies" as follows:

Instead of following these simple and well-known guidelines, many authors today invoke analogy by citing one, or perhaps two, analogical cases from anywhere in the world that seem somehow related to the argument at hand. I refer to these arguments as "ad-hoc analogies." There is little consideration for sampling or formal comparison. Ad hoc analogies provide no support at all for the argument at hand. The fact that some human group somewhere in the world did something vaguely similar to what you are claiming for your archaeological case does not in fact support your claim. (Smith, 2015b:20)

(2) Empty citations are bibliographic references to works that do not contain any data supportive of the case at hand. Instead, they merely signal works that make a point similar to the point of the author. Such works are cited to lend an aura of support to the argument, when in fact they contain no empirical support at all. Empty citations are included in a work to falsely inflate the apparent strength or quality of an analogical argument. The classic discussion of empty citations is a paper by Anne-Wil Harzing (2002); other analyses include Todd et al. (2010), Henige (2011), and Abbott (2010).

(3) The use of heuristic analogues is a growing practice in archaeology with parallels in the field of historical climate change and sustainability science. For the latter realm, Meyer et al. (1998) contrast formal and heuristic analogies. A formal analogy is an argument employing inductive logic, as outlined above. Heuristic analogues are less rigorous comparisons of whole societies or systems. Typically, a complex historical (or archaeological) setting or event is compared with conditions today, without any formal testing. "They are heuristic because they are too complex or too contextually different to be formally specified" (Meyer et al., 1998:220). Examples include historical episodes (e.g., the collapse of an empire), and events (a plague); these can be based on historical narratives, archaeological data, paleoenvironmental reconstructions, or ethnographic documentation. Jared Diamond's (2004) analyses of societal collapses are heuristic analogues, as are the cases promoted by Michael Glantz $(1991 ; 2019)$ in what he called "forecasting by analogy." While such analogues can be enlightening and educational, they rarely provide a rigorous scientific explanation or understanding (Dearing et al., 2010). They do not permit testing, and they do not conform to the criteria for a successful inductive (formal analogical) argument.

Archaeologists are increasingly offering heuristic analogues in the name of argument by analogy. The procedure tends to go as follows. The archaeologist wants to explain attributes of a particular past cultural context, often a social or institutional setting; this is the target case. He or she chooses a better-documented parallel case (from history, archaeology, or ethnography), and asserts that the two settings are sufficiently similar to apply information from the well-described case to the target case. This permits numerous details from the former to be simply applied to the 
latter without testing. Keith Eppich (2020), for example uses information from medieval Italy to illuminate Classic Maya society, and Maxime Lamoureux-St-Hilaire (2020) generalizes this process of heuristic analogue comparison for interpreting Classic Maya society. See also Davide Domenici's (2018) application of Aztec evidence to Teotihuacan. In his discussion of argument by analogy, Matthew Johnson (2010:66-69) phrases a number of hypothetical examples in terms of this kind of whole-society comparison. Additional critiques of this kind of complex untested analogue are found in the literature on comparisons in the discipline of history (Kocka, 2003; Sewell, 1967).

\section{The Popularity of Abstract Social Theory}

For many archaeologists, "theory" has come to be synonymous with highly abstract social theory. While this body of thought may be useful for understanding the social world on a very general, philosophical level, it is not of much help for understanding the basic human activities, institutions, and social conditions that comprise human life and society on a daily basis. High-level theory is very broad and applicable to many situations, but its empirical content is quite low (Abend, 2008; Mills, 1959; Tilly, 2008; Bunge, 1999). In the social sciences, most explanatory theory is of a lower epistemological level, and it is often called "middle-range theory" (Merton, 1968). This concept has almost nothing in common with the notion of middlerange theory as used by Lewis Binford (1983; 1989); for comment, see Raab and Goodyear (1984), or Smith (2015b).

Because of the highly abstract epistemological level of much social theory in archaeology (Thomas, 2015), it is hard to make rigorous empirical arguments. Concepts such as practice theory, materiality, alterity and assemblage theory are consistent with a staggeringly broad range of propositions, to the point where it can be difficult to determine when a particular argument is supported or not. Proponents of these approaches find it difficult or unpleasant to frame their arguments in a fashion that can be tested, including formal inductive analogies. While some archaeological arguments can be framed in a way that allows their accuracy or success to be tested, in other cases arguments can be evaluated for their empirical strength. For this situation, Stephen Toulmin's research on the structure of arguments is very useful for archaeologists.

\section{The Structure of Arguments: Stephen Toulmin's Scheme}

"An argument is a connected series of statements intended to establish a proposition" (Monty Python, 1989:86). In 1958 Stephen Toulmin introduced a new formal approach to argumentation to the philosophy of science (Toulmin, 2003). In place of the former schemewhich was based on major premises, minor premises and conclusions - his approach emphasized the varied nature of facts and their level of support. He introduced the strength of arguments as an important consideration, using a diagram (Figure 1) to show the logical trajectory from data or facts to the claim. Warrants, which providing justification and support for the claim, are a key feature. This scheme was then developed for archaeology by Chapman and Wylie (2016), where I first encountered it; see also Bonnin (2019) for an account relevant to archaeology.

The following summary is based on Toulmin (2003) Chapman and Wylie (2016) and Bonnin (2019). Bonnin suggests that to begin the process, facts are preferable to data, the term used by Toulmin. Data connotes the total information generated by a project, whereas facts better describe the specific pieces of data arrayed for a given argument. The line from facts to claims is supported by warrants. Warrants are "general, hypothetical statements, which act as bridges and 
authorize the sort of step to which our particular argument commits us" (Toulmin, 2003:91). This is probably the most important innovation of Toulmin's approach.

Toulmin's concept of warrant was incorporated into the generalized argument structure described in the textbook, The Craft of Research (Booth et al., 2008:chapter 7). These authors define warrant as a "general principle that justifies relating your particular reason to your particular claim" (p. 114). I have suggested that most warrants in archaeological arguments consist of either comparative data or theory (Smith, 2015b:20). Analogy is one of the formal ways that comparative data are employed as warrants. Warrants are justified and supported by backings. Bonnin (2019:6) defines backings as "further facts that can be brought to ensure the applicability of the warrants by specifying that the circumstances in which the warrants are applied are the right ones. Backings are secondary facts used in support of warrants. Backings are distinguished from facts functionally."

Rebuttals "identify exceptions and delimit the scope of an argument (Chapman and Wylie, 2016:35); they "indicate specific circumstances in which the claim made would turn out to be invalid" (Bonnin, 2019:4). Finally, qualifiers describe the quality and strength of the evidence (facts, warrants, backings) as it relates to the strength of the argument. Toulmin's (2003) examples of qualifiers include "This must be the case," "This may be the case," as well as terms such as certainly, probably, and possibly. These are difficult to incorporate into the basic diagram.

Chapman and Wylie (2016) provide a number of complex archaeological arguments diagrammed with Toulmin's scheme, and I refer readers to that source for an excellent discussion. Toulmin's diagrams are a useful way to highlight differences in argumentation between a scientific approach to archaeology and an interpretivist, postprocessual approach. As I explain in Smith (2017) I use the phrase "scientific approach" to describe research that uses a scientific epistemology (i.e., systematic, testable claims, and generalizing), not research that employs specific analytical techniques from the hard sciences. Instead of using the graphical representation of arguments, I employ a list format that permits a more efficient use of space; these lists can be easily transformed into the graphical form of Figure 1. For clarity of comparison, I limit consideration to relatively simple arguments for the use or significance of domestic artifacts and features.

Two arguments from my own research are shown in Figure 2. Argument 1-that small bowls were tools used in hand-spinning cotton - is supported by a number of warrants, each supported in turn by solid backings (Smith and Hirth, 1988; Smith, 2015a). As a result, this is a strong argument that is widely accepted by archaeologists. The warrants and backings for Argument 2-that large houses at Aztec rural provincial sites were elite residences - are not quite as secure as in the first case, and therefore this argument is not as strong (Olson and Smith, 2016; Smith, 1992). I judge "very likely" as an appropriate qualifier for this argument.

Figure 3 portrays two weak interpretivist arguments for the meanings of ceramic figurines in term of political ideology. ${ }^{2}$ Most archaeologists would probably agree that any interpretation of the meaning of ancient objects will be less secure-weaker - than most interpretations of the uses of objects or buildings. Indeed, many archaeologists are of the opinion that meanings cannot be recovered for ancient objects in the absence of texts (Flannery and Marcus, 1993). One advantage of Toulmin's scheme is that it allows us to see precisely where the weaknesses in such arguments lie. 
In Argument 3, Elizabeth Brumfiel (1996) makes the claim that the attributes and contexts of female ceramic figurines imply that the dominant ideology of the Aztec state was resisted by commoners. The warrants she gives are noteworthy for their low level of support by backings. Some have no (stated) backings at all, and others are simply weak. Warrant 2 is backed by an abstract theoretical position that can be reconciled with a number of conflicting claims, and Warrant 4 is backed by citing the opinions of other scholars, rather than empirical findings. This is an example of empty citation, as discussed above. Warrants 1 and 5 are basically assertions. I suggest the qualifier, "It is possible that" indicates the level of strength of this argument. Brumfiel (1996:161) qualifies her argument as follows: "where the influence of the dominant ideology is felt, it does not always result in ideological dominance." While this is a somewhat vague conclusion, it does provide some qualification to her central claim.

In Argument 4, Christina Halperin (2009) builds on Brumfiel's paper to make a related argument about the role of figurines in transmitting a dominant ideology. As in Argument 3, the backings here are quite weak; they include abstract theoretical positions (Warrants 2 and 3), and assertions (Warrants 4 and 5). Again, this is a weak and speculative argument, but that does not stop the author from making rather definite claims without qualification; one example is her conclusion: "figurines aided in the dissemination of state symbols and ideologies" (Halperin, 2009:396).

If archaeologists were to use Toulmin's scheme to discuss and present their arguments, they might be induced to provide more realistic qualifiers of the strength of those arguments. This is, in fact, a fundamental requirement of arguments in science. Arguments "should never be a categorical assertion, but should always convey the author's assessment of the credibility of his own claims" (Ziman, 1978:64); see also 6 and Bellamy (2012:36-37). In some fields - such as climate change research by the Intergovernmental Panel on Climate Change-scientists have developed a coding system for explicitly indicating the strength of every claim (Adler and Hirsch Hadorn, 2014; Ebi, 2011), something archaeologists should consider doing.

\section{Models as Arguments}

A model is a simplified representation of some part of the world created in order to better understand the organization and dynamics of that part of the world. In the words of John Ziman (1978:23), a model is "no more than an analogy or metaphor. It implies a structure of logical and mathematical relations that has many similarities with what it purports to explain, but cannot be fully identified with it." Following the definitions of arguments and models employed in this paper, models can be seen as a type of argument, and arguments can in turn be seen as a type of model.

In spite of their abstract similarity, these two concepts - models and arguments-are rarely discussed together in archaeology. Each has its own literature, with relatively few citations across one another. Chapman and Wylie (2016) include discussion of both in their book, but they are included in separate chapters without cross-references. These authors only connect the two concepts at an abstract level, where arguments and models are both components or strands of the cables of evidence and inference that make up archaeological knowledge of the past. I suggest that in order to achieve a more comprehensive view of argumentation in archaeology, it is useful to view models as a type of argument. Models begin with a set of facts, they are manipulated by the analyst in ways analogous to warrants, and the end result is a claim. 
From the perspective of argumentation, archaeological models consist of two sequential arguments. The first argument-which I will call the internal argument-is the model itself. The second, or external, argument is the operation that links the results of the model to some aspect of the past, or to a more general realm of social or ecological processes. Archaeological works on modeling devote most or all of their attention to the internal arguments (Clarke, 1972; Wylie, 2017b; van der Leeuw and McGlade, 1997; Kohler and van der Leeuw, 2007; Romanowska et al., 2019). The external argument — usually called the validation of the model —is where the results are compared to external data to assess the degree of fit (Cegielski and Rogers, 2016; McGlade, 2014).

I use the terms internal and external deliberately to line up with the concepts of internal and external validity in the field of social science methodology. Internal validity asks whether a finding is true for a chosen sample. That is, does the model operate properly and produce results that make sense given the inputs and methods? External validity asks whether a given finding can be generalized to a broader population of cases (Gerring, 2012:84). James McGlade (2014:288), in discussing issues in archaeological simulation models, stresses the need for "a stronger focus on epistemological issues, rather than on technological/methodological preoccupations," and this suggestion can be mapped onto the internal/external division. Indeed, the preoccupation of modelers with internal validity at the expense of external validity parallels the situation in the field of economics. In the words of philosopher of science Nancy Cartwright:

Economists make a huge investment to achieve rigor inside their models, that is to achieve internal validity. But how do they decide what lessons to draw about target situations outside from conclusions rigorously derived inside the model? That is, how do they establish external validity? We find: thought, discussion, debate; relatively secure knowledge; past practice; good bets. But not rules, check lists, detailed practicable procedures; nothing with the rigor demanded inside the models." (Cartwright, 2007:18)

Perhaps an acknowledgement of models as two-part arguments may promote greater attention to epistemology by archaeological modelers, as called for by McGlade (2014).

\section{Conclusions}

One of the negative consequences of the period when argumentation and epistemology receded in archaeology is that weak arguments have become tolerated. Weak arguments are now a regular feature of peer reviewed publications. Their conclusions - often based on abstract social theory combined with scanty empirical evidence with no testing - are not reliable, preventing the development of a strong foundation of solid archaeological evidence. While this situation may be acceptable to those with an interpretivist orientation - where concerns are local with little concern for generalization - a scientific perspective requires the creation of a reliable body of findings, and those findings must rely on adequate forms of argumentation.

The chapters in this book contribute to a growing trend of published studies on argumentation in archaeology. In addition to the suggestions of other chapters, I propose that attention to the form and structure of arguments can improve the reliability and usefulness of the claims we make from archaeological data. The works of philosophers of science who focus on 
social science and history (Toulmin, 2003; Little, 2010; Wylie, 2002) are very helpful in this regard, but it is up to archaeological practitioners to do what it takes to improve our arguments.

A continuing methodological advancement in argumentation will have two benefits. First, it will help create a more robust record of archaeological knowledge, thereby improving our understanding of past societies and cultures around the world. Second, it will allow archaeological data to be used in transdisciplinary research that goes beyond the confines of our discipline (Smith, n.d.) and contributes to broader research questions in the social, natural, and historical sciences.

\section{Acknowledgements}

An email exchange with Alison Wylie helped organize my thoughts on several issues of argumentation. Iza Romanowska, Stefani Crabtree, and several other archaeological modelers on Twitter stimulated my thinking on models and their relationship with arguments.

\section{Figure List}

Figure 1. Stephen Toulmin's diagram for arguments. Graphic by Michael E. Smith, based on Toulmin (2003:97).

Figure 2. Schematic depiction of two strong arguments from the author's research. Argument 1 is based on Smith and Hirth (1988) and Smith (2015a); argument 2 is based on Olson and Smith (2016).

Figure 3. Schematic depiction of two weak arguments. Argument 3 is from Brumfiel (1996); argument 4 is in Halperin (2009).

\section{References Cited}

6, P., \& Bellamy, C. (2012). Principles of Methodology: Research Design in Social Science. New York: Sage.

Abbott, A. (2004). Methods of Discovery: Heuristics for the Social Sciences. New York: Norton.

Abbott, A. (2010). Varieties of Ignorance. American Sociologist, 41, 174-189.

Abend, G. (2008). The Meaning of "Theory". Sociological Theory, 26, 173-199.

Adler, C. E., \& Hirsch Hadorn, G. (2014). The IPCC and Treatment of Uncertainties: Topics and Sources of Dissensus. Wiley Interdisciplinary Reviews: Climate Change, 5(5), 663-676. doi:10.1002/wcc.297.

Binford, L. R. (1981). Bones: Ancient Men and Modern Myths. New York: Academic Press. Binford, L. R. (1983). In Pursuit of the Past: Decoding the Archaeological Record. New York: Thames and Hudson.

Binford, L. R. (1989). Debating Archaeology. New York: Academic Press.

Bonnin, T. (2019). Evidential reasoning in historical sciences: applying Toulmin schemes to the case of Archezoa. Biology and Philosophy, 34(2), 30.

Booth, W. C., Colomb, G. G., \& Williams, J. M. (2008). The Craft of Research. Chicago:

University of Chicago Press. 
Brumfiel, E. M. (1996). Figurines and the Aztec State: Testing the Effectiveness of Ideological Domination. In R. P. Wright (Ed.), Gender and Archaeology (pp. 143-166). Philadelphia: University of Pennsylvania Press.

Bunge, M. (1999). Social Science under Debate: A Philosophical Perspective. Toronto: University of Toronto Press.

Bunge, M. (2004). How Does It Work?: The Search for Explanatory Mechanisms. Philosophy of the Social Sciences, 34(2), 182-210.

Bunge, M. (2013). Bruce Trigger and the Philosophical Matrix of Scientific Research. In S.

Chrisomalis, \& A. Costopolous (Eds.), Human Expeditions: Inspired by Bruce Trigger (pp. 143159). Toronto: University of Toronto Press.

Cartwright, N. (2007). Are RCT's the Gold Standard? BioSocieties, 2(1), 11-20.

Cegielski, W. H., \& Rogers, J. D. (2016). Rethinking the role of Agent-Based Modeling in archaeology. Journal of Anthropological Archaeology, 41, 283-298.

doi:http://dx.doi.org/10.1016/j.jaa.2016.01.009.

Chapman, R., \& Wylie, A. (Eds.) (2015). Material Evidence. (New York: Routledge)

Chapman, R., \& Wylie, A. (2016). Evidential Reasoning in Archaeology. New York:

Bloomsbury Press.

Clark, G. A. (2000). On the Questionable Practice of Invoking the Metaphysic. American Anthropologist, 102(4), 851-853.

Clarke, D. L. (Ed.) (1972). Models in Archaeology. (London: Methuen)

Copi, I. M. (1982). Introduction to Logic. New York: Macmillan.

Currie, A. (2016). Ethnographic analogy, the comparative method, and archaeological special pleading. Studies in History and Philosophy of Science Part A, 55, 84-94.

Dearing, J. A., Braimoh, A. K., Reenberg, A., Turner, B. L., II, \& van der Leeuw, S. (2010). Complex Land Systems: The Need for Long Time Perspectives to Assess their Future. Ecology and Society, 15(4), article 21 (published online).

http://www.ecologyandsociety.org/vol15/iss4/art21/.

Demeulenaere, P. (Ed.) (2011). Analytical Sociology and Social Mechanisms. (New York: Cambridge Universitiy Press)

Diamond, J. (2004). Collapse: How Societies Choose to Fail or Succeed. New York: Viking.

Domenici, D. (2018). Beyond Dichotomies: Teotihuacan and the Mesoamerican Urban

Tradition. In D. Domenici, \& N. Marchetti (Eds.), Urbanized Landscapes in Early SyroMesopotamia and Prehispanic Mesoamerica: Papers of a Cross-Cultural Seminar held in Honor of Robert McCormick Adams (pp. 35-70). Wiesbaden: Otto Harrassowitz.

Ebi, K. L. (2011). Differentiating Theory from Evidence in Determining Confidence in an Assessment Finding. Climate Change, 108, 693-700.

Eppich, K. (2020). Analogy as Theory and Method. The SAA Archaeological Record, 20(1), 31-

34.

Flannery, K. V. (1973). Archaeology with a Capital S. In C. L. Redman (Ed.), Research and Theory in Current Archaeology (pp. 47-58). New York: Wiley.

Flannery, K. V., \& Marcus, J. (1993). Cognitive Archaeology. Cambridge Archaeological Journal, 3, 260-270.

Fogelin, L. (2007). Inference to the Best Explanation: A Common and Effective form of Archaeological Reasoning. American Antiquity, 72, 603-625. 
Gerring, J. (2012). Social Science Methodology: A Unified Framework. New York: Cambridge University Press.

Gibbon, G. (2014). Critically Reading the Theory and Methods of Archaeology: An Introductory Guide. Lanham, MD: Rowman and Littlefield.

Glantz, M. H. (1991). The use of analogies: In forecasting ecological and societal responses to global warming. Environment: Science and Policy for Sustainable Development, 33(5), 10-33.

Glantz, M. H. (2019). Societal responses to regional climatic change: forecasting by analogy. New York: Routledge.

Haber, S. (1999). Anything Goes: Mexico's "New" Cultural History. Hispanic American Historical Review, 79, 309-330.

Halperin, C. T. (2009). Figurines as Bearers of and Burdens in Late Classic Maya State Politics. In C. T. Halperin, K. A. Faust, R. Taube, \& A. Giguet (Eds.), Mesoamerican Figurines: SmallScale Indices of Large-Scale Social Phenomena (pp. 378-403). Gainesville: University Press of Florida.

Harzing, A.-W. (2002). Are Our Referencing Errors Undermining our Scholarship and Credibility? The Case of Expatriate Failure Rates. Journal of Organizational Behavior, 23, $127-$ 148.

Hedström, P. (2005). Dissecting the Social: On the Principles of Analytical Sociology. New York: Cambridge University Press.

Hegmon, M. (2003). Setting Theoretical Egos Aside: Issues and Theory in North American Archaeology. American Antiquity, 68, 213-243.

Hempel, C. (1965). Aspects of Scientific Explanation. New York: Free Press.

Henige, D. P. (2011). Truth or Hope? Stimulus and Response in Scholarly Publishing. Journal of Scholarly Publishing, 42(2), 205-225.

Hodder, I., \& Hutson, S. R. (2003). Reading the Past. Cambridge: Cambridge University Press.

Johnson, M. (2010). Archaeological Theory: An Introduction. Oxford: Blackwell.

Kerr, N. L. (1998). HARKing: Hypothesizing After the Results are Known. Personality and Social Psychology Review, 2(3), 196-217.

Kocka, J. (2003). Comparison and Beyond. History and Theory, 42, 39-44.

Kohler, T. A., \& van der Leeuw, S. E. (Eds.) (2007). Model-Based Archaeology of Socionatural Systems. (Santa Fe: SAR Press)

Lamoureux-St-Hilaire, M. (2020). Comparative Approaches and Analogical Reasoning for Mayanists. The SAA Archaeological Record, 20(1), 8-13.

Leung, K. (2011). Presenting Post Hoc Hypotheses as A Priori: Ethical and Theoretical Issues. Management and Organization Review, 7(3), 471-479.

Little, D. (2010). New Contributions to the Philosophy of History. New York: Springer.

Mahoney, J., Kimball, E., \& Koivu, K. L. (2009). The Logic of Historical Explanation in the Social Sciences. Comparative Political Studies, 42(1), 114-146.

Manicas, P. T. (2006). A Realist Philosophy of Social Science: Explanation and Understanding. New York: Cambridge University Press.

Martinón-Torres, M., \& Killick, D. (2013). Archaeological Theories and Archaeological Sciences. In A. Gardner, M. Lake, \& U. Sommer (Eds.), Oxford Handbook of Archaeological Theory New York: Oxford University Press (published online). 
McGlade, J. (2014). Simulation as Narrative: Contingency, Dialogics, and the Modeling Conundrum. Journal of Archaeological Method and Theory, 21(2), 288-305.

Merton, R. K. (1968). Social Theory and Social Structure. New York: Free Press.

Meyer, W. B., Butzer, K. W., Downing, T. E., II, B. L. T., Wenzel, G. W., \& Wescoat, J. L. (1998). Reasoning by Analogy. In S. Rayner, \& E. L. Malone (Eds.), Human Choice and Climate Change, volume 3: Tools for Policy Analysis (pp. 217-289). Columbus: Battelle Press.

Mills, C. W. (1959). The Sociological Imagination. New York: Oxford University Press.

Monty Python. (1989). The Complete Monty Python's Flying Circus: All the Words, Volume 2.

New York: Pantheon Books.

Morgan, C. G. (1973). Archaeology and Explanation. World Archaeology, 4(3), 259-276.

Moro Abadía, O., \& Lewis-Sing, E. (2021). The Decline of Epistemology in Archaeology: Comments on an Ongoing Discussion. In L. Coltofean-Arizancu, \& M. Díaz-Andreu (Eds.), Interdisciplinarity and Archaeology: Scientific Interactions in Nineteenth- and TwentiethCentury Archaeology (pp. 203-223). Oxford: Oxbow Books.

Olson, J. M., \& Smith, M. E. (2016). Material Expressions of Wealth and Social Class at AztecPeriod Sites in Morelos, Mexico. Ancient Mesoamerica, 27(1), 133-147.

Orser, C. E., Jr. (2014). Archaeological Thinking: How to Make Sense of the Past. Lanham, MD: Rowman and Littlefield.

Popper, K. R. (1934). The Logic of Scientific Discovery. New York: Harper and Row.

Raab, L. M., \& Goodyear, A. C. (1984). Middle-Range Theory in Archaeology: A Critical Review of Origins and Applications. American Antiquity, 49, 255-268.

Ragin, C. C., \& Amoroso, L. M. (2011). Constructing Social Research: The Unity and Diversity of Method. Thousand Oaks, CA: Sage.

Romanowska, I., Crabtree, S. A., Harris, K., \& Davies, B. (2019). Agent-Based Modeling for Archaeologists: Part 1 of 3. Advances in Archaeological Practice, 7(2), 178-184. doi:DOI: 10.1017/aap.2019.6.

Sabloff, J. A., Beale, T. W., \& Kurland, A. M., Jr. (1973). Supplement: Recent Developments in Archaeology. Annals of the American Academy of Political and Social Science, 408, 103-118.

Sewell, W. H. (1967). Marc Bloch and the Logic of Comparative History. History and Theory, 6(2), 208-218.

Smith, M. E. (1992). Archaeological Research at Aztec-Period Rural Sites in Morelos, Mexico. Volume 1, Excavations and Architecture / Investigaciones arqueológicas en sitios rurales de la época Azteca en Morelos, Tomo 1, excavaciones y arquitectura. University of Pittsburgh.

Smith, M. E. (Ed.) (2015a). Artefactos Domésticos de Casas Posclásicas en Cuexcomate y Capilco, Morelos. (Oxford: Archaeopress)

Smith, M. E. (2015b). How Can Archaeologists Make Better Arguments? The SAA Archaeological Record, 15(4), 18-23.

Smith, M. E. (2017). Social Science and Archaeological Inquiry. Antiquity, 91(356), 520-528.

Smith, M. E. (n.d.). Why Archaeology's Relevance to Global Challenges Has Not Been Recognized. Antiquity, (in press).

Smith, M. E., \& Hirth, K. G. (1988). The Development of Prehispanic Cotton-Spinning Technology in Western Morelos, Mexico. Journal of Field Archaeology, 15, 349-358.

Thomas, J. (2015). The Future of Archaeological Theory. Antiquity, 89, 1287-1296.

Tilly, C. (2008). Explaining Social Processes. Boulder, CO: Paradigm Publishers. 
Todd, P. A., Guest, J. R., Lu, J., \& Chou, L. M. (2010). One in four citations in marine biology papers is inappropriate. Marine Ecology Progress Series, 408, 289-303.

Toulmin, S. (2003). The Uses of Arguments. New York: Cambridge University Press.

Trigger, B. G. (2006). A History of Archaeological Thought. New York: Cambridge Univ. Press. van der Leeuw, S. E., \& McGlade, J. (Eds.) (1997). Time, Process, and Structured Transformation in Archaeology. (New York: Routledge)

Watson, P. J., LeBlanc, S. A., \& Redman, C. L. (1971). Explanation in Archaeology: An Explicitly Scientific Approach. New York: Colombia University Press.

Watson, P. J., LeBlanc, S. A., \& Redman, C. L. (1974). The covering law model in archaeology: Practical uses and formal interpretations. World Archaeology, 6(2), 125-132.

Wylie, A. (1985). The Reaction Against Analogy. Advances in Archaeological Method and Theory, 8, 63-111.

Wylie, A. (Ed.) (2002). Thinking from Things: Essays in the Philosophy of Archaeology. (Berkeley: University of California Press)

Wylie, A. (2017a). From the Ground Up: Philosophy and Archaeology. Proceedings of the American Philosophical Association, 91, 118-136.

Wylie, A. (2017b). Representational and Experimental Modeling in Archaeology. In L. Magnani, \& T. Bertolotti (Eds.), Springer Handbook of Model-Based Science (pp. 989-1002). New York: Springer.

Ziman, J. (1978). Reliable Knowledge: An Exploration of the Grounds for Belief in Science. New York: Cambridge University Press.

\footnotetext{
${ }^{1}$ See Moro Abadía (2021) for an alternative view of the decline of archaeological epistemology in the late twentieth century. He employs a notion of epistemology at odds with the standard scientific realist approach employed by most archaeologists (Trigger, 2006; Chapman and Wylie, 2016), allowing him to promote "anti-epistemological" theoretical standpoints (p. 212).

${ }^{2}$ I chose these examples because they are two of the cases that sparked my inquiry into the strength of arguments (Smith, 2015b). I saw these as particularly weak or problematic arguments whose validity could not easily be tested.
}

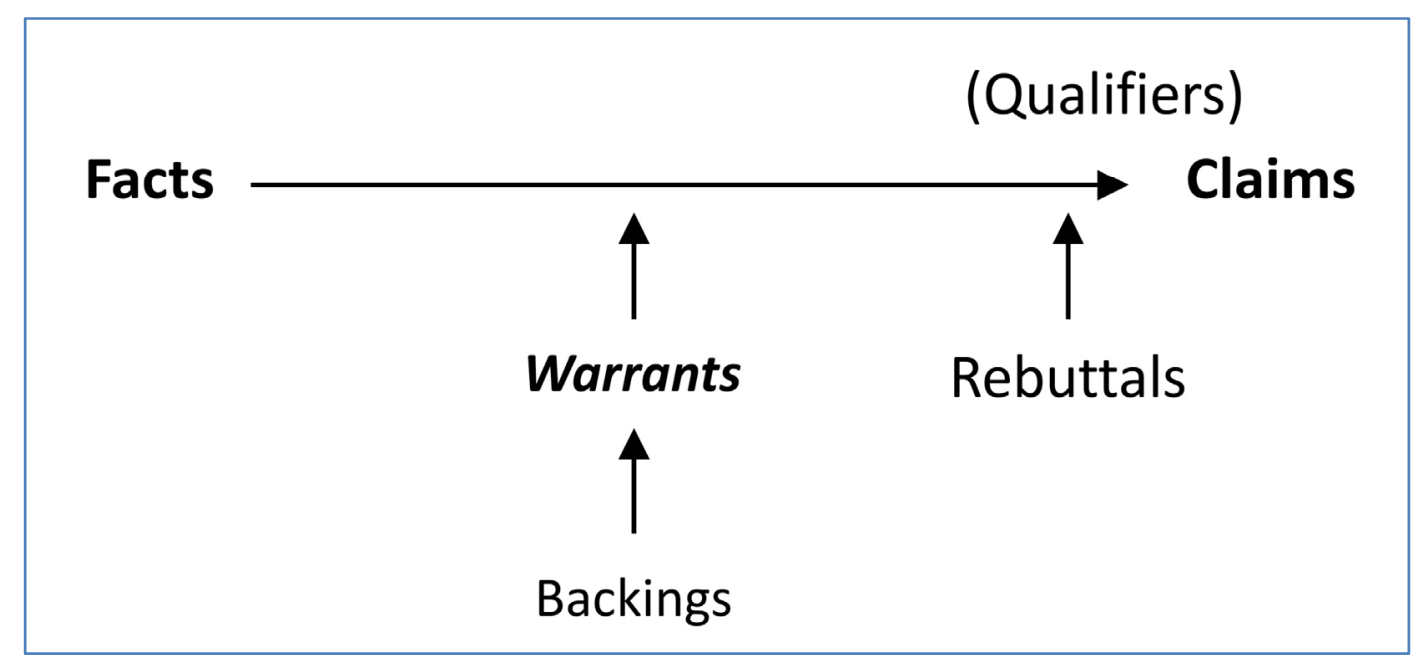

FIGURE 1 
ARGUMENT 1 (Smith \& Hirth 1988)

\begin{tabular}{|c|c|}
\hline Fact & Sherds from small bowls excavated in domestic contexts \\
\hline Claim & These small bowls were used to spin cotton \\
\hline Warrant 1 & Spinning cotton requires a bowl \\
\hline Backing 1 & The stapel length of cotton requires control of the spindle \\
\hline Backing 2 & Hand-spinners of cotton today use a smal bowl \\
\hline Warrant 2 & Physical attributes are consistent with use in spinning \\
\hline Backing 1 & Abrasion occurs in locations consistent with a twirling spindle \\
\hline Backing 2 & Bowls are highly standardized in diameter \\
\hline Warrant 3 & Cotton was grown in this area \\
\hline Backing 1 & Cotton pollen was recovered in excavation \\
\hline Backing 2 & Historical documents mention cotton cultivation in this region \\
\hline Warrant 4 & Pictorial sources show Aztec women spinning with small bowls \\
\hline Rebuttal & Unless these were toys, \\
\hline Qualifier & It is almost certain that, \\
\hline Claim & These small bowls were used to spin cotton \\
\hline
\end{tabular}

ARGUMENT 2 (Olson \& Smith 2016)

\begin{tabular}{|c|c|}
\hline Fact & Variation in house size at Aztec-period sites in Morelos \\
\hline Claim & The larger structures were elite residences \\
\hline Warrant 1 & Social theory and past research suggests the presence of elites \\
\hline Backing 1 & Written sources identify elites in Aztec society \\
\hline Backing 2 & All known Mesoamerican state-level societies likely had elites \\
\hline Warrant 2 & Architectural attributes resemble elite housing in other early societies \\
\hline Backing 1 & A few structures are much larger than most houses \\
\hline Backing 2 & More expensive materials and painted decoration \\
\hline Backing 3 & Built on raised platforms, unlike most houses \\
\hline Warrant 3 & Associated artifacts are typical of elite residences \\
\hline Backing 1 & The artifacts are domestic in function \\
\hline Backing 2 & There are more high-velue items than at most houses \\
\hline Rebuttal & Unless these were a previously unidentified specialized structure, \\
\hline Qualifier & It is very likely that, \\
\hline Claim & The larger structures were elite residences \\
\hline
\end{tabular}

\section{FIGURE 2}


ARGUMENT 3 (Brumfiel 1996)

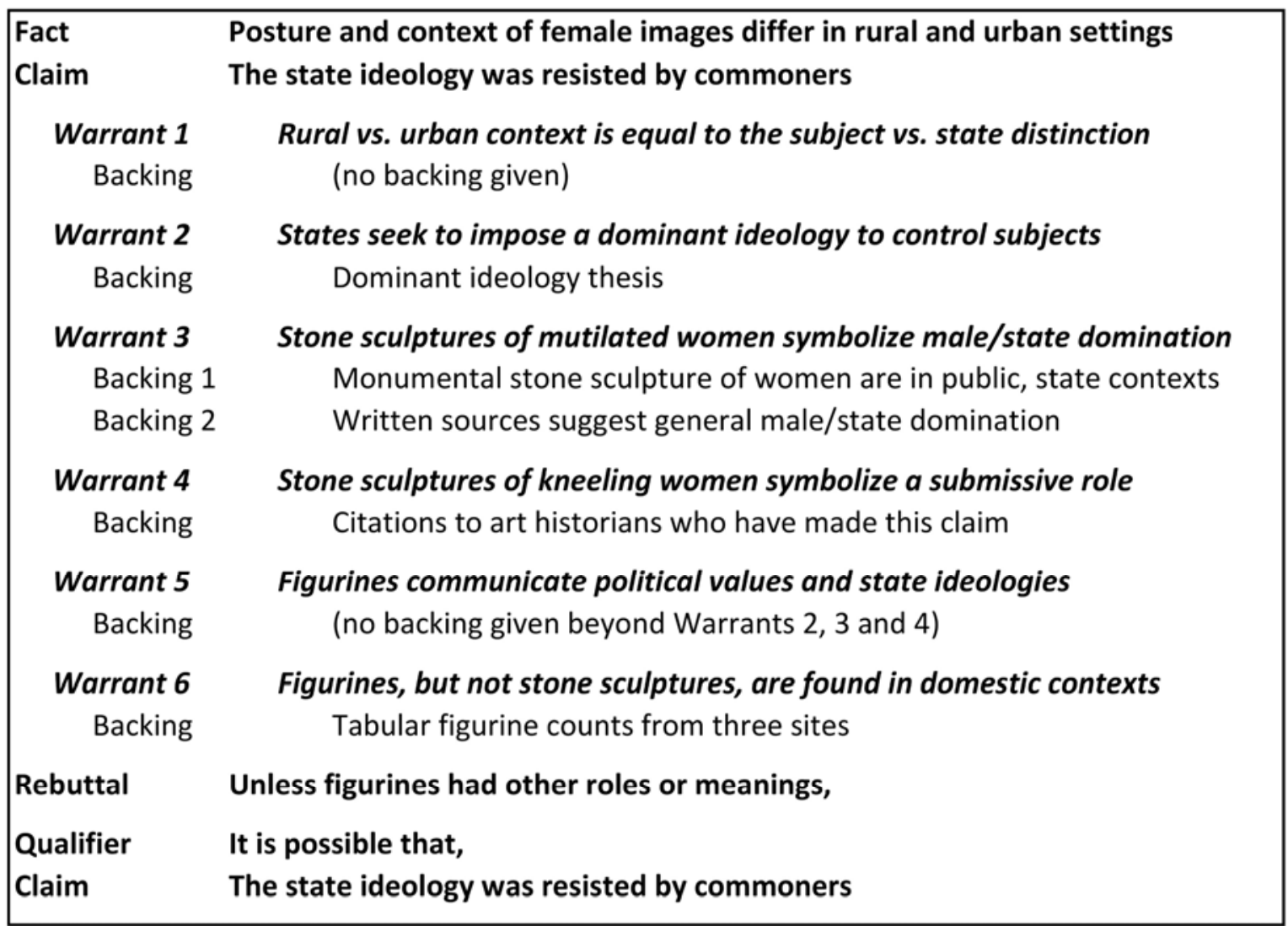

ARGUMENT 4 (Halperin 2009)

\begin{tabular}{|c|c|}
\hline Fact & Mold-made figurines of males with headress excavated in domestic contexts \\
\hline Claim & The state used figurines to impose ideology on commoners \\
\hline Warrant 1 & Mold-made figurines imply mass production \\
\hline Backing & Figurines from the same mold found in separated contexts \\
\hline Warrant 2 & States seek to impose a dominant ideology to control subjects \\
\hline Backing & Dominant ideology thesis \\
\hline Warrant 3 & Mass produced objects inhibit political action \\
\hline Backing & Claims of Frankfort-school philosophers about capitalist society \\
\hline Warrant 4 & Figurines communicate political values and state ideologies \\
\hline Backing & (no backing given beyond Warrants 2 and 3 ) \\
\hline Warrant 5 & Figurines are found in domestic contexts \\
\hline Backing & Verbal claim in the text \\
\hline Rebuttal & Unless figurines had other roles or meanings, \\
\hline Qualifier & It is possible that, \\
\hline Claim & The state used figurines to impose ideology on commoners \\
\hline
\end{tabular}

\section{FIGURE 3}

